\title{
REVITALISASI FUNGSI HUTAN PANTAI MELALUI PROGRAM REBOISASI HUTAN LINDUNG DAN KONSERVASI HUTAN MANGROVE DI KAWASAN PANTAI UJONG BLANG KECAMATAN BANDA SAKTI KOTA LHOKSEUMAWE
}

\author{
Widya Arwita $^{1 *}$, Makharany Dalimunthe ${ }^{1}$, Roza Thohiri $^{2}$ \\ ${ }^{1}$ Fakultas Matematika dan Ilmu Pengetahuan Alam, Universitas Negeri Medan, Medan, Indonesia \\ ${ }^{2}$ Fakultas Ekonomi, Universitas Negeri Medan, Medan, Indonesia \\ *Penulis Korespondensi: widyaarwita@unimed.ac.id
}

\begin{abstract}
Abstrak
Kerusakan hutan mangrove dan hutan pantai di pesisir pantai Ujong Blang di Kecamatan Banda Sakti menjadi isu sentral dari kajian deskriptif-kualitatif ini. Ulasan ini menganalisis secara interpretatif dari pelaksanaan program CSR Oleh PT. PERTAMINA (Persero) Marketing Operating Region (MOR) I Terminal Bahan Bakar Minyak (TBBM) Lhokseumawe guna mengatasi dampak negatif penurunan keanekaragaman hayati pada ekosistem hutan mangrove dan hutan pantai Ujong Blang sekaligus menguatkan kapasitas masyarakat secara kolegial dan formil dalam mengelola kawasan hutan mangrove dan hutan pantai Ujong Blang sesuai fungsi fisik, biologi dan sosial-ekonomi yang relevan. Kampanye dan edukasi pelestarian dan pengelolaan lingkungan alam ini menjadi efektif dengan paritispasi aktif kelompok masyarakat pelestari lingkungan pantai Ujong Blang dari 5 (lima) desa terkait: Hagu Selatan, Hagu Teungoh, Hagu Barat Laot, Ulee Jalan dan Ujong Blang dalam reboisasi 3.000 batang pohon lindung dengan 3 (tiga) jenis vegetasi masing-masing sebanyak 1.000 pohon yakni: 1) Ketapang (Terminalia Catappa); 2) Ketapang Kencana (Terminalia Mantaly) dan; 3) Cemara Laut (Casuarina Equisetifolia) serta dilanjutkan dengan konservasi hutan mangrove melalui penanaman bibit mangrove sebanyak 10.000 pohon dalam tahun 2018 sebagai upaya untuk menjaga ekosistem dan keanekaragaman hayati di hutan mangrove dan hutan pantai Ujong Blang yang berbasis pengelolaan dari dan oleh komunitas masyarakat sekitar yang berkesinambungan dan kebermanfaatannya akan terus dirasakan hingga generasi selanjutnya.
\end{abstract}

Kata Kunci: Reboisasi Hutan Pantai, Konservasi Hutan Mangrove, Keanekaragaman Hayati, Pantai Ujong Blang

\begin{abstract}
The destruction of mangrove and coastal forests on the coastal area of Ujong Blang in Banda Sakti Subdistrict became a central issue from this descriptive-qualitative study. This paper analyzes interpretatively on the implementation of CSR programs By PT. PERTAMINA (Persero) Marketing Operating Region (MOR) I - Lhokseumawe Fuel Oil Terminal (TBBM) to overcome the negative impacts of biodiversity degradation on the mangrove forest ecosystem and the Ujong Blang coastal forest supported by efforts in strengthening collegial and formal local community capacity in managing mangrove forest and Ujong Blang coastal forests in accordance with their physical, biological and socio-economic functions. These preservation and management of the natural environment campaign and education have performed as an effective tool highlighting the active paritalization of coastal environmental conservation groups of Ujong Blang who are from 5 (five) related villages: South Hagu, Hagu Teungoh, Hagu Barat Laot, Ulee Jalan and Ujong Blang in reforestation of 3,000 protected tree trunks with 3 (three) types of vegetation each of 1,000 trees, namely: 1) Ketapang (Terminalia Catappa); 2) Ketapang Kencana (Terminalia Mantaly) and; 3) Cemara Laut (Casuarina Equisetifolia). Accordingly, the program is continued with the conservation of mangrove forests through planting 10,000 mangrove seedlings in 2018 as an effort to maintain ecosystems and biodiversity in mangrove forests and the coastal management of Ujong Blang that are locally managed by the formalized Ujong Blang's environmental community towards gaining continuous benefits for generations in future.
\end{abstract}

Keywords: Coastal Reforestation, Mangrove Conservation, Biodiversity, Ujong Blang Coast 


\section{PENDAHULUAN}

Berbagai kajian akademik telah menegaskan pentingnya keberadaan hutan mangrove bagi penciptaan ekosistem dan ekologi kehidupan di sekitarnya secara berkelanjutan (lihat Suryani, 2018; Feka, 2015; Dale et al., 2014). Secara khusus, Martuti (2013) menjelaskan bahwa hutan mangrove sebagai sebuah ekosistem yang berada di wilayah intertidal mempunyai keanekaragaman hayati yang majemuk dihasilkan dari interaksi perairan laut, payau, sungai dan terrestrial. Kekayaan flora dan fauna yang terkandung didalam ekosistem hutan mangrove juga memiliki nilai ekonomi yang tinggi dimana jika tidak dapat dikontrol dengan baik maka akan berdampak kepada kerusakan ekosistem dan ekologi di kawasan hutan mangrove.

Kondisi inilah yang lazim ditemukan di berbagai wilayah nusantara. Kajian yang dilakukan oleh Fauzi (2014) dan KKMTN (2013) menunjukkan bahwa areal hutan mangrove di Indonesia terus mengalami penurunan (terindikasi telah berkurang sebanyak hampir 1,1 juta ha sejak kurun waktu 20 tahun terkahir) dimana salah satu pemicu utamanya adalah eksploitasi oleh industri dan masyarakat untuk pembangunan maupun untuk kepentingan konsumsi masyarakat itu sendiri. Disisi lain, kondisi kerusakan hutan mangrove tidak dibarengi oleh upaya reboisasi dan konservasi yang relevan dan berkesinambungan sehingga mengakibatkan semakin tidak produktifnya ekosistem dalam wilayah hutan mangrove yang telah rusak tersebut.

Salah satu dampak negatif yang ditimbulkan dari eksploitasi tidak terkendali pada wilayah hutan mangrove adalah bencana abrasi yang memperparah potensi banjir di kawasan pemukiman di sekitar pantai akibat minimnya keberadaan pohon-pohon mangrove yang memiliki akar yang kuat dan kokoh dalam mengurangi laju erosi perairan pantai. Dalam konteks yang lebih masif, tidak berfungsinya fisik hutan mangrove juga membuat ombak tsunami menjadi lebih mudah memasuki wilayah pemukiman di daratan yang tidak hanya membawa kerusakan fisik disekitarnya namun juga ancaman kehilangan nyawa penduduk yang berdomisili di wilayah sekitar.

Kecamatan Banda Sakti di Kota Lhokseumawe merupakan salah satu kecamatan di Kota Lhokseumawe dengan posisi geografis sebelah utara dan timur berbatasan dengan perairan Selat Malaka (BPS, 2017). Potensi bencana abrasi juga kerap mengintai wilayah pemukiman di beberapa desa (gampong) di wilayah Kecamatan Banda Sakti tanpa kompromi. Secara khusus ketika bencana Gempa dan Tsunami yang melanda daerah pesisir Nanggroe Aceh Darussalam pada 26 Desember 2004 yang lalu; beberapa pemukiman di Desa Pusong dan Desa Ujong Blang di Kecamatan Banda Sakti turut terkena dampak kerusakan yang cukup parah yang juga mengakibatkan puluhan korban jiwa meninggal dunia. Namun, hingga lebih dari satu dekade berselang, kondisi hutan mangrove dan hutan pantai masih relatif belum mengalami perbaikan yang signifikan. Menurut laporan Center for Economic and Society Development (CESD) Fakultas Ekonomi dan Bisnis Universitas Malikusaleh, sebelum dilakukan pengembangan kepariwsataan di Kecamatan Banda Sakti khususnya di pesisir pantai Desa Ujong Blang pada tahun 1990an; areal hutan mangrove mencakup lahan seluas $90.600 \mathrm{~m}^{2}$ atau sebesar 33,92\% dari total luas sempadan pantai dengan areal gisik/pasiran pantai alami tanpa penutup lahan buatan seluas $63.091 \mathrm{~m}^{2}$ atau sebesar 23,62\%. Dalam laporan yang oleh CESD ditujukan sebagai scope of works kegiatan yang dikembangkan di wilayah sekitar kepada PT. PERTAMINA (Persero) MOR I - TBBM Lhokseumawe juga dipaparkan fakta bahwa telah terjadi perubahan fungsi lahan hutan mangrove dan hutan pantai Ujong Blang secara khusus bagi peruntukan kegiatan komersial seperti warung rujak, kafetaria, rumah makan dan pemukiman penduduk dengan cakupan wilayah seluas $45,15 \%$ dari total luas sempadan pantai. Saat ini, CESD juga mengindikasikan bahwa luas masing-masing hutan mangrove dan gisik sebesar $2,87 \%$ dan $2,37 \%$ dari total lahan sempadan pantai yang mencakup $267.100 \mathrm{~m}^{2}$. Hingga saat ini, dalam periode pasang purnama yakni pada bulan Oktober sampai Desember menjadi periode kritis bagi masyarakat sekitar Pantai Ujong Blang. Dalam periode ini, intensitas dampak primer (rumah panggung dan gazebo yang runtuh dan hanyut akibat terjangan ombak pantai) serta dampak sekunder (hilangnya ekosistem bahari dan potensi ekonomi nelayan akibat pendangkalan air laut dari maraknya rumah semi permanen dan warung yang dibangun di pinggiran pantai) menjadi permasalahan serius bagi kelangsungan hidup warga sekitar.

Belajar dari dampak kerusakan yang ditimbulkan oleh bencana tsunami dan tsunami yang melanda wilayah Kecamatan Banda Sakti hingga saat ini, PT. PERTAMINA (Persero) MOR I - TBBM Lhokseumawe mengaktualisasikan pertangungjawaban sosialnya dengan kemitraan bersama CESD telah merealisasikan program konservasi dan reboisasi hutan mangrove dan hutan pantai di Pantai Ujong Blang. Realisasi program ini menjadi upaya nyata bagi sinergitas fungsi fisik, biologis dan sosial-ekonomi hutan mangrove dan hutan pantai di Kecamatan Banda Sakti secara berkelanjutan bagi peningkatan kehidupan masyarakat setempat. Selain itu, upaya ini menjadi perwujudan komitmen dan dedikasi korporasi bagi pemenuhan prinsip tata kelola yang baik khususnya melalui pemenuhan Undang-Undang Nomor 40 tahun 2007 Pasal 74 ayat (1), (2), (3), dan (4) dalam kaitannya dengan implementasi tanggung jawab sosial dan lingkungan kepada Masyarakat di wilayah operasional TBBM Lhokseumawe, dalam hal ini adalah di kawasan dalam wilayah Kecamatan Banda Sakti.

Tulisan ini bermaterikan kajian yang mengulas secara deskriptif dengan metode analisis data kualitatif dari pelaksanaan program oleh PT. PERTAMINA (Persero) MOR I - TBBM Lhokseumawe. Tulisan ini juga 
menjadi referensi akademik atas efektivitas dan efisiensi capaian yang dilakukan oleh korporasi dalam mengejawantahkan tanggung jawab sosial dan lingkungannya kepada penerima manfaat.

\subsection{Profil Penerima Manfaat - Kecamatan Banda Sakti: Dimensi Geografi dan Demografi}

Kota Lhokseumawe merupakan pemekaran dari Kabupaten Aceh Utara dan terletak di pesisir timur Pulau Sumatra. Posisi Kota Lhokseumawe berada di antara Kota Banda Aceh dan Medan, menjadikan kota ini sangat strategis sebagai jalur distribusi dan perdagangan di Aceh. Hingga saat ini Kota Lhokseumawe terdiri atas empat kecamatan 68 gampong/desa, 9 mukim, dan 259 dusun.

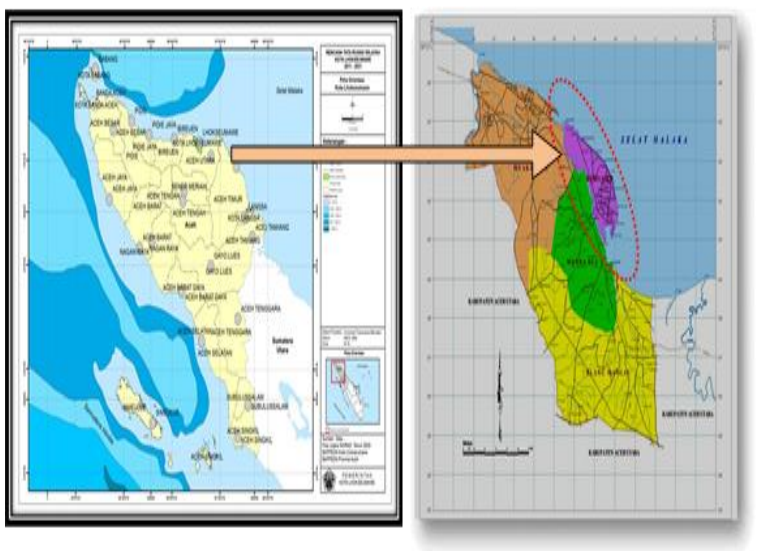

Gambar 1.

Kiri : Peta Administrasi Kota Lhokseumawe

Kanan: Peta wilayah Kecamatan Banda Sakti (dilingkari)

(sumber: Dokumentasi CESD)

Dikutip dari publikasi BPS Lhokseumawe dalam Angka tahun 2015 oleh CESD (unpublished); Kota Lhokseumawe dengan luas 181,06 Km2 terletak di antara $4^{\circ}-5^{\circ}$ Lintang Utara dan $96^{\circ}-97^{\circ}$ Bujur Timur dengan ketinggian rata-rata 13 meter di atas permukaan laut. Batas-batas wilayah Kota Lhokseumawe, sebelah Utara berbatasan dengan Selat Malaka, sebelah Selatan dengan Kecamatan Kuta Makmur (Aceh Utara), sebelah Timur dengan Kecamatan Syamtalira Bayu (Aceh Utara), dan sebelah Barat dengan Kecamatan Dewantara (Aceh Utara). Jumlah penduduk Kota Lhokseumawe adalah sebanyak 187.455 jiwa terdiri atas 93.403 jiwa laki-laki dan 94.052 jiwa perempuan. Kecamatan Banda Sakti adalah kecamatan dengan jumlah penduduk terbanyak dengan proporsi sekitar 43 persen dari total penduduk Lhokseumawe atau 80.769 jiwa. Pada tahun 2014 tercatat jumlah pencari kerja di Kota Lhokseumawe adalah sebanyak 2.213 orang terdiri dari 842 laki- laki dan 1.371 perempuan. Dari jumlah ini, sekitar $29 \%$ diantaranya berpendidikan sarjana muda atau sarjana.

Selanjutnya dalam laporannya CESD (unpublished), juga memaparkan bahwa Kecamatan Banda Sakti terletak di Kota Lhokseumawe terdiri dari 18 Desa, dengan luas wilayah 11,24 $\mathrm{km}^{2}$ dengan jumlah penduduk sebanyak 80.769 jiwa. Kecamatan Banda Sakti merupakan daerah pesisir pantai dan dataran. Curah hujan tertinggi terjadi pada Bulan November sebesar 294,5 mm, sedangkan curah hujan terendah terjadi pada Bulan Februari sebesar $50 \mathrm{~mm}$. Jumlah hari hujan tertinggi terjadi pada Bulan November sebanyak 25 hari, sedangkan jumlah hari hujan terendah terjadi pada Bulan Februari sebanyak 9 hari.

Secara khusus, BPS (2017) memetakan bahwa 9 (sembilan) desa di Kecamatan Banda Sakti berbatasan dengan laut (Selat Malaka) khususnya yakni Pusong Lama, Pusong Baru, Lhokseumawe, Ulee Jalan, Hagu Barat Laut, Hagu Teungoh, hagu Selatan dan Kampung Jawa Lama. Pantai Ujong Blang merupakan wilayah dengan potensi wisata pantai yang menawan dan menjadi daerah tujuan wisata favorit bagi Masyarakat Kota Lhoskeumawe dan sekitarnya tetapi sekaligus sebagai kawasan yang rawan terhadap bencana abrasi/gelombang pasang. Walaupun telah dilakukan pembangunan tanggul penahan gelombang akan tetapi belum maksimal untuk menahan tekanan gelombang laut terutama pada musim pasang naik. Perlu adanya penanganan untuk mengurangi tekanan gelombang laut sehingga dapat mempertahankan wilayah pantai dari bahaya abrasi (CESD, unpublished).

Penerima manfaat dari CSR oleh PT. PERTAMINA (Persero) MOR I - TBBM Lhokseumawe merupakan komunitas masyarakat nelayan di desa Hagu Selatan, Hagu Teungoh, Hagu Barat Laot, Ulee Jalan dan Ujong Blang. Berdasarkan kajian dari CESD, kawasan di kelima desa tersebut diproyeksikan menjadi zonasi wisata pantai, sehingga pada kawasan ini dicanangkan berbagai fasilitas wisata dan konservasi serta industri kerajinan kreatif terpadu sebagai penyangga aktivitas pengembangan kawasan desa wisata mandiri, kawasan pariwisata, dan kawasan industri dalam arti luas. Di kawasan ini juga diperuntukkan bagi menunjang ekonomi masyarakat, sekaligus sebagai pusat pengembangan industri pariwisata yang dapat mengintegrasikan aktivitas masyarakat pedesaan, perikanan dan keindahan potensi alam.

Secara spesisifk, studi awal yang dilakukan oleh CESD juga menunjukkan bahwa kondisi SDM penduduk wilayah di 5 (lima) desa setempat didominasi oleh lulusan SD dengan lulusan SMP, dan SMA dan perguruan tinggi dalam jumlah yang relatif kecil. Hal ini menunjukkan adanya kesenjangan pendidikan yang sangat tajam. Sebagian besar penduduk bekerja di sektor non formal (2.203 orang) dan tingginya angka pengganguran. Pada musim hujan/disertai angin, penduduk tidak melakukan aktivitas melaut dan berkonsentrasi pada pemenuhan kebutuhan sehari-hari melalui perkebunan, dan peternakan.

Dengan daya dukung luas wilayah yang cukup memadai dan panorama alam yang indah, dengan kuantitas jumlah nelayan yang cukup signifikan, wilayah kecamatan ini sangat berpotensi untuk jadi zona wisata, sentra perikanan yang bisa memenuhi 
kebutuhan pangan dan meningkatkan kondisi ekonomi masyarakat menuju wilayah desa-desa wisata yang mandiri.

\section{HASIL DAN PEMBAHASAN}

2.1 Program Konservasi Hutan Mangrove dan Reboisasi Hutan Pantai Ujong Blang

\section{1) Realisasi}

Hingga triwulan III tahun 2018, kemitraan PT. PERTAMINA (Persero) MOR I - TBBM Lhokseumawe telah melakukan penanaman 3.000 batang pohon lindung dengan 3 (tiga) jenis vegetasi masing-masing sebanyak 1.000 pohon yakni:

1) Ketapang (Terminalia Catappa)

2) Ketapang Kencana (Terminalia Mantaly)

3) Cemara Laut (Casuarina Equisetifolia)

Realisasi program juga mencakup pendirian dan pemberdayaan kelompok tani Mangrove Banda Sakti yang akan melanjutkan program konservasi pohon mangrove sebanyak 10.000 batang di areal konservasi hutan mangrove setempat. Di sisi penguatan kapasitas mitigasi bencana, PT. PERTAMINA (Persero) MOR I - TBBM Lhokseumawe juga melakukan aktivitas pelatihan pelestarian lingkungan dan kesiapsiagaan terhadap bencana berbasis komunitas Sadar Lingkungan dan Siaga Bencana.

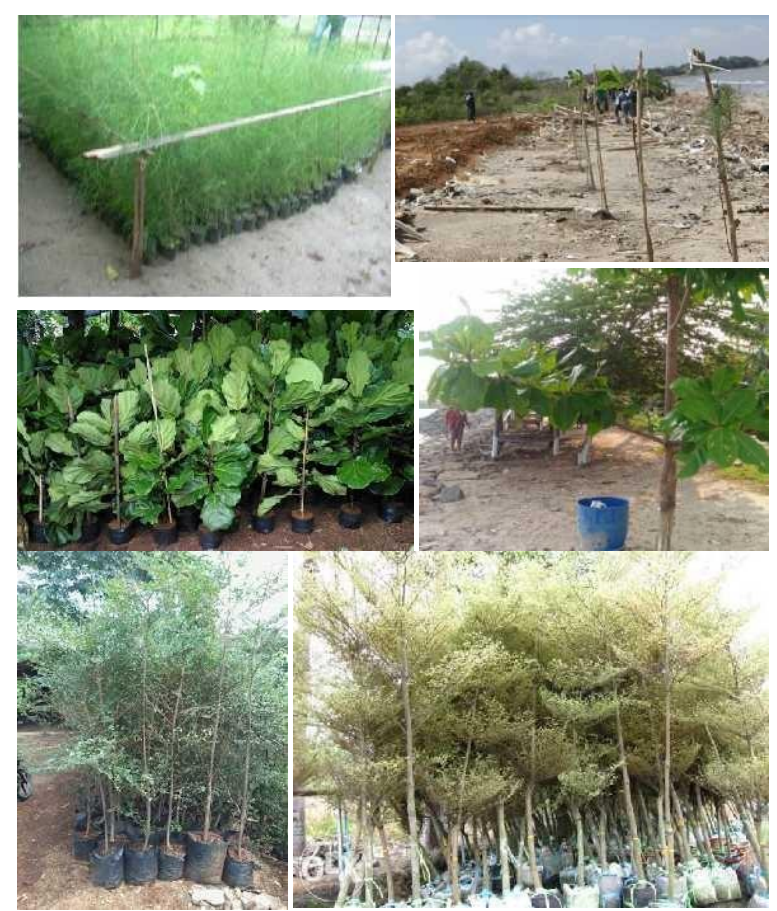

Gambar 2. Jenis Tanaman Hutan Lindung yang ditanam (dokumen CESD)

PT. PERTAMINA (Persero) MOR I - TBBM Lhokseumawe memandang penting integrasi peran serta diantara berbagai stakeholder yang ada sehingga menjadikan fokus utama dari implementasi CSR bagi pengembangan kawasan konservasi dan restorasi hutan mangrove di daerah pesisir Kecamatan Banda Sakti demi mempercepat proses terwujudnya keseimbangan fungsi ekosistem dan proses ekologi wilayah pesisir dan laut secara menyeluruh. Kampanye pelestarian lingkungan ini juga diapresiasi secara penuh oleh masyarakat setempat dan dampaknya telah dirasakan oleh masyarakat sekitar berupa mulai meningkatnya popularitas kawasan hutan mangrove pesisir Kecamatan Banda Sakti sebagai alternatif wisata baru di Kota Lhokseumawe seria hasil panen ikan dan kepiting yang berdampak pada peningkatan pendapatan dari masyarakat nelayan setempat.

\section{2) Efektifitas dan Efisiensi Capaian}

Implementasi program CSR oleh PT. PERTAMINA (Persero) MOR I - TBBM Lhokseumawe melalui kampanye perlidungan keanekaragaman hayati dalam bentuk Program Konservasi dan Reboisasi Kawasan Pantai Ujong Blang Kota Lhokseumawe memberikan dampak positif bagi warga khususnya masyarakat nelayan di desa Hagu Selatan, Hagu Teungoh, Hagu Barat Laot, Ulee Jalan dan Ujong Blang yang merupakan kawasan zonasi wisata pantai yang rentan terhadap dampak negatif perubahan garis pantai dan penggunaan lahan sempadan pantai. Perubahan fungsi penggunaan lahan sempadan pantai tersebut merupakan faktor yang sangat kuat untuk mempercepat proses erosi (abrasi) pantai. Salah satu dampak yang sering dialami oleh penduduk di sekitar kawasan pantai Ujong Blang akibat perubahan fungsi lahan sempadan pantai adalah serangan ombak dan badai bahkan masuknya air laut ke permukiman penduduk yang berjarak 500 meter dari pantai terutama dalam periode pasang purnama, yaitu pada bulan Oktober sampai Desember dimana rumah penduduk, fasiltas umum (mushalla, gedung sekolah, jalan desa), sarana pariwisata mengalami rusak parah, dan tidak bisa digunakan lagi.

Penguatan fungsi fisik, biologi dan sosial-ekonomi dari kawasan hutan pantai di Pantai Ujong Blang Kota Lhokseumawe berbasis pemberdayaan kelompok masyarakat setempat telah memfasilitasi tata ruang kepariwisataan dengan penyediaan lahan konservasi serta industri kerajinan kreatif terpadu sebagai penyangga aktivitas pengembangan kawasan desa wisata mandiri, kawasan pariwisata, dan kawasan industri dalam arti luas. Integrasi aktivitas masyarakat pedesaan, perikanan dan keindahan potensi alam juga telah diarahkan ke lokasi yang memisahkan kawasan komersil dengan kawasan konservasi dan hutan lindung sesuai fungsi aslinya.

Proses pelaksanaan program yang bersifat partisipatif dengan melibatkan anggota masyarakat, nelayan atau pemangku kepentingan dari sektor kelautan/desa memberikan kesempatan dan perhatian serta meningkatkan kesadaran masyarakat sehubungan dengan sumberdaya alam dan berbagai masalah terkait serta memberikan kerangka bagi pelaksanaan program. Hal ini selaras dengan kajian oleh Martuti et al. (2018), Idrus et al. (2016) dan Wardhani, (2011) yang menggarisbawahi pelibatan komponen masyarakat penerima manfaat sebagai faktor keberhasilan kunci 
(key success factor) dalam upaya pemulihan dan pelestarian ekosistem kawasan pesisir pantai dalam hal ini melalui program reboisasi dan konservasi hutan lindung dan hutan mangrove di kawasan pantai Ujong Blang di Kecamatan Banda Sakti Kota Lhokseumawe.

Partisipasi masyarakat setempat juga menjadi langkah strategis dalam efektivitas dan efisiensi capaian program yang dimaksud dimana pembentukan kelembagaan komunitas masyarakat pelestari lingkungan di Kecamatan Banda Sakti selaras dengan amanat UU Nomor 32 Tahun 2009 tentang pengelolaan dan perlindungan lingkungan hidup yang menekankan peran aktif masyarakat dalam upaya perlindungan dan pengelolaan lingkungan hidup sekitar (Martuti et al., 2013).

\section{KESIMPULAN DAN IMPLIKASI}

Program Konservasi dan Reboisasi Kawasan Pantai Ujong Blang Kota Lhokseumawe memiliki kontribusi yang signifikan bagi pemberdayaan kelompok masyarakat pelestari lingkungan kawasan pantai, setempat. Secara visual, capaian pelaksanaan program dapat dilihat dari perbaikan pada 3 (tiga) aspek utama yakni:

- Fisik - dalam jangka pendek, menengah dan panjang berdampak pada revitalisasi kondisi lingkungan yang ada bagi penurunan dampak negatif perubahan garis pantai dan penggunaan lahan sempadan pantai yang berpotensi mengakibatkan terjadinya erosi (abrasi) pantai.

- Ekologi - spesies dari vegetasi hutan pantai yang memiliki persyaratan ekologi yang relevan.

- Ekonomi - menjadi proyek rintisan pengembangan kawasan ekowisata yang terintegrasi dengan sektor industri pendukung lainnya dengan masyarakat sebagai actor utama dalam pengelolaan kawasan ekowisata: rekreasi, pendidikan dan olahraga. Selain itu, aspirasi masyarakat dan stakeholder akan aktualisasi kebutuhan dan keinginan dari masyarakat setempat dapat terpenuhi dengan melalui penyediaan akses langsung terhadap wilayah yang ditanami.

Kegiatan ini penting untuk ditindaklanjuti dengan legalisasi kelompok masyarakat pelestari lingkungan pantai Ujong Blang sehingga kelembagaan formal yang dimaksud akan menjadi bagian yang tidak terpisahkan dari tata kelola sistem penyelenggaraan pemerintah di wilayah tersebut. Hal ini menjadi krusial karena upaya reboisasi hutan pantai ini telah relatif bagus sehingga capaian pelaksanaannya akan dirasakan kebermanfaatannya secara berkesinambungan hingga ke generasi berikutnya. Selain itu, pengembangan pelaksanaan program kepada konservasi hutan mangrove dengan penanaman bibit sebanyak 10.000 pohon harus dikelola secara professional dengan pendampingan yang berkelanjutan dari stakeholder khususnya di Kecamatan Banda Sakti dan Kota Lhokseumawe pada umumnya.

\section{DAFTAR PUSTAKA}

Dale, P. E. R., Knight, J. M, and Dwyer, P. G. (2014). Mangrove Rehabilitation: A Review Focusing on Ecological and Institutional Issues. Wetlands Ecology Management. Vol. 22: 587-604.

Fauzi, A. (2014). Valuasi Ekonomi dan Penilaian Kerusakan Sumber Daya Alam dan Lingkungan. IPB Press. Bogor.

Feka, Z. N. (2015). Sustainable Management of Mangrove Forests in West Africa: A New Policy Perspective. Ocean \& Coastal Management. 116. 341-352.

Idrus, S., Ismail, A., dan Ekayani, M. (2016). Potensi Pembayaran Jasa Lingkungan Hutan Mangrove di Kecamatan Jailolo Kabupaten Halmahera Barat. Jurnal Ilmu Pertanian Indonesia. Vol. 21 (3): 195-202.

KKMTN (Kelompok Kerja Mangrove Tingkat Nasional). (2013). Strategi Nasional Pengelolaan Ekosistem Mangrove Indonesia (buku 1). Jakarta. [diunduh pada 21 September 2018]. Tersedia pada: http://indonesia.wetlands.org

Martuti, N. K. T., Susilowati, S. M. E., Sidiq, W. A. B. N, dan Mutiatari, D. P. (2018). Peran Kelompok Masyarakat dalam Rehabilitasi Ekosistem Mangrove di Pesisir Kota Semarang. Jurnal Wilayah dan Lingkungan. Vol. 6 (2): 100-114.

Suryani, N. (2018). Kajian Ekosistem Hutan Mangrove di Muara Sungai Batang Manggung Kecamatan Pariaman Utara Kota Pariaman Provinsi Sumatera Barat. Jurnal Geografi. Vol. 10 (2): 144-156.

Wardhani, M. K. (2011). Kawasan Konservasi Mangrove: Suatu Potensi Ekowisata. Jurnal Kelautan. Vol. 4 (1): 60-76. 